\title{
Screening and Analysis of Probiotic Properties of Lactobacillus Spp. From Famous Commercial Brand of Yogurt Found in Kathmandu Valley
}

\author{
Asmita Khanal ${ }^{1,2}$ and Niranjan Koirala ${ }^{1 *}$ \\ ${ }^{1}$ Dr. Koirala Research Institute for Biotechnology and Biodiversity, Department of Natural Products Research, Nepal. \\ ${ }^{2}$ Research Center for Applied Science and Technology, Tribhuvan University, Nepal
}

Submission: February 20, 2019; Published: March 18, 2019

*Corresponding author: Dr. Niranjan Koirala PhD, Dr. Koirala Research Institute for Biotechnology and Biodiversity, Department of Natural Products Research, Kathmandu, Nepal

\begin{abstract}
Probiotics are live microbial strains that have a positive impact on human health by maintaining the gut microflora. Probiotics are present in fermented food products. Out of many probiotics, most belongs to Lactobacillus genera which are also used in commercial food products. Yoghurt is a potential source of probiotic lactobacilli. The purpose of this study is to identify and analyse the probiotic properties of isolated Lactobacillus spp. from different five commercial brand of yoghurt that are famous in Kathmandu valley.

All the isolate was identified on the basis of their morphological and biochemical characteristics. These identified isolates were further examined to analyze the probiotic properties which includes tolerance to inhibitory substances like phenol( $0.4 \%)$, Nacl (1-9\%) and bile acid (0.1$1 \%)$; the ability to grow in acidic (pH 2.5) and alkaline (pH8.5) condition and their antimicrobial activities along with susceptibility to selected nine antibiotics which was determined by disk diffusion method. The result of this present study indicates that the isolates from commercial yoghurts sample fulfill the most common criteria of probiotic bacteria with slight variation among the sample in different properties.
\end{abstract}

Keywords: Probiotics; Lactobacillus spp; Antimicrobial; Yoghurts; Kathmandu Valley

\section{Introduction}

Probiotics are living microorganism that stimulates the health of the host by maintaining the intestinal microflora. Probiotic bacteria mainly consists a genera of Lactic Acid-Producing Bacteria (LAB), including Lactobacillus and Bifidobacterium, streptococcus and some enterrococcus spp. [1]. Traditionally fermented food product including dairy product such as yoghurt is the major source of probiotic [2].

Yoghurt is a cultured dairy product that has been fermented with LAB. Fermentation of lactose by these bacteria produces lactic acid, whose action on milk proteins results the texture and characteristics flavour of yogurt. The properties like lactic acid production, antimicrobial properties, antibiotic tolerance, bile tolerance, $\mathrm{pH}$ tolerance and gastric juice resistance are some criteria for the in vitro selection of lactobacilli to be used as probiotic [3]. It is very important that probiotic strain should survives in the area where it is supposed to be active.

The strain should able to proliferate and colonize at the specific location to boost maximum activity. Probiotics for human consumption should have 'generally regarded as safe'. It should be tolerated by immune system and should not be pathogenic, allergic, or mutagenic [4]. Probiotic assist in the prevention and treatment of Gastrointestinal infections and diseases [5]. The benefits of Lactobacillus spp ranges from reducing allergies, preventing antibiotic-associated diarrhea [6], removing cholesterol [7], prevent urinary tract infection, stimulation and development of immune system of the host [8].

Yoghurt has been a part of a human daily diet, with the increasing awareness about the health benefits of yoghurts consumption, the interest and market of yoghurt has increased globally. In Nepal, yoghurt is locally called 'dahi' and consumed as a part of a daily diet. Here, yoghurt has been produced in a household level but with the increasing number of population and changing lifestyle, the demand of commercial yoghurt is rising. Respectable evidence continues to emerge that shows that the members of the genus Lactobacillus are widely used in the manufacturing of yoghurt [9].

Despite growing use and consumption of Lactobacillus as probiotics, which can enhance the health status of large segment of communities, there is a lack of scientific research on local commercial yoghurts in Kathmandu. Therefore, this study is undertaken to find potential probiotics properties of Lactobacillus spp. from a famous commercial brand of yoghurt in Kathmandu Valley. 


\section{Materials and Methods}

\section{Collection of samples}

Total five yoghurt samples from different commercial dairy in Kathmandu were collected from market as freshly as prepared. The samples were stored aseptically in low temperature $\left(4^{\circ} \mathrm{C}\right)$ refrigerator to protect from contamination and deterioration immediately after collection.

\section{Media}

The bacteria Lactobacillus spp. was isolated from each sample by using DeMann, Rogosa and Sharpe (MRS) media both MRS broth and MRS agar media [10]. In order to improve the specificity of the medium for isolation of Lactobacillus $0.05 \%$ cysteine was added [11]. The final pH of the media was adjusted to 6.5 .

\section{Isolation and identification of bacteria}

All the required instrument and media were autoclaved for 15 min at $120^{\circ} \mathrm{C}$. One gram of each sample was suspended in $100 \mathrm{ml}$ respective MRS broth and after dissolving they were shaken homogeneously. All this homogenized sample were subjected to fivefold dilution, these dilutions were than incubated for 24 hours for $37^{\circ} \mathrm{C}$ under anaerobic condition in the presence of $10 \% \mathrm{CO}_{2}$ to remove unwanted bacteria. From each broth, a loopful of culture was streaked on to the MRS agar media which were incubated for 24 hours at $37^{\circ} \mathrm{C}$ [12]. Finally, the single colony of bacteria was isolated and identified by observing their morphological characteristics and some biochemical tests like Gram staining, catalase, endospore test, motility test and milk coagulation activities. The cultures were maintained in the MRS broth.

\section{Screening of isolated Lactobacillus Spp. for probiotic properties}

Determination of optimal growth and $\mathbf{p H}$ : For the determination of optimal $\mathrm{pH}$ and growth, the overnight culture of the Lactobacillus in the MRS broth media with a varying $\mathrm{pH}$ ranging from 2.5 to 8.5 , using $\mathrm{Hcl}$ or $\mathrm{NaOH}$ were inoculated with $1 \%(\mathrm{v} / \mathrm{v})$ and incubated in anaerobic condition for $24 \mathrm{~h}$ at $37^{\circ} \mathrm{C}$ in the presence of $10 \% \mathrm{CO}_{2}$. Bacterial growth was monitored by the determination

\section{Results and Discussion}

\section{Isolation and identification}

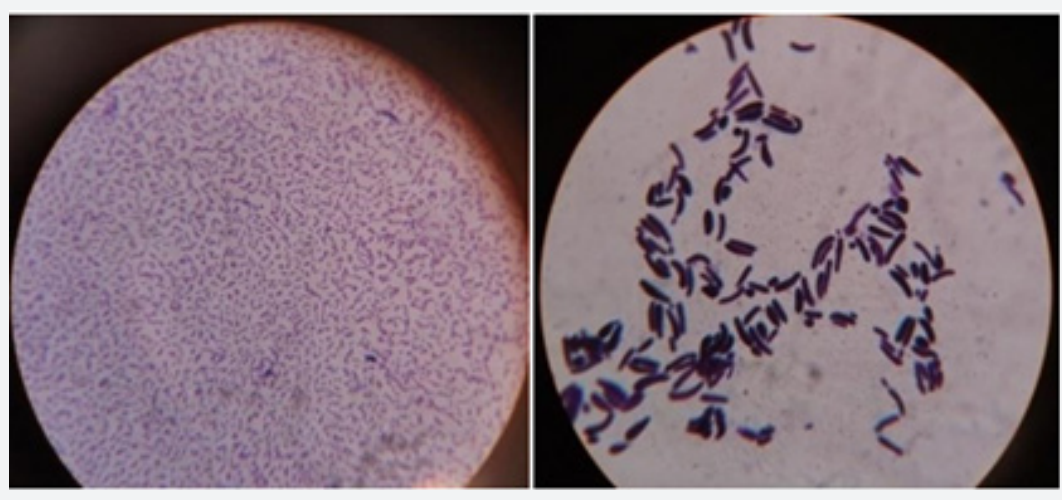

Figure 1: Gram staining of isolated Lactobacillus spp.

of optical density at $560 \mathrm{~nm}$ using a spectrophotometer against the uninoculated broth [13].

Assay for NaCl tolerance: In order to determine the $\mathrm{NaCl}$ tolerance, isolates from each sample were incubated with $1 \%(\mathrm{v} / \mathrm{v})$ overnight culture of Lactobacillus in the test tubes containing MRS broth adjusted with different concentrations (1-10\%) of NaCl. The inoculated medium was incubated in anaerobic condition for $24 \mathrm{~h}$ at $37^{\circ} \mathrm{C}$. The bacterial growth was determined using spectrophotometer reading the optimal density at $560 \mathrm{~nm}[14]$.

Determination of bile salt tolerance: Bile salt tolerance of the isolated bacteria was examined by inoculating the freshly cultured isolates at $1 \%(\mathrm{v} / \mathrm{v})$ into MRS broth containing Bile salt at different concentrations $(0,0.1,0.3,0.5$ and $1 \%(\mathrm{w} / \mathrm{v})$. The medium was then incubated at $37^{\circ} \mathrm{C}$ for 24 hours in an anaerobic condition. The growth of the isolates was monitored at $0,3,5$ and $24 \mathrm{~h}$ by measuring the absorbance of the culture broth at $620 \mathrm{~nm}$ using spectrophototometer [13].

Antimicrobial activity: The antimicrobial activity of the isolated Lactobacillus was identified by well diffusion method [15], with slight modification. The overnight culture of Lactobacillus was centrifuged $\left(10,000 \mathrm{rpm}\right.$ for $20 \mathrm{~min}$. at $\left.4^{\circ} \mathrm{C}\right)$ and the supernatant was adjusted to pH 7.0 with $\mathrm{NaOH}$ to exclude the antimicrobial effect of $\mathrm{H}^{+}$. Supernatant of each sample of Lactobacillus were monitored for antibacterial activity against indicator bacteria (Escherichia Coli, Staphylococcus aureus, Salmonella typhi, Bacillus subtilis) inoculated on Nutrient agar. Wells of $5 \mathrm{~mm}$ in diameter were punctured into the agar plate and aliquots of $50 \mu \mathrm{l}$ from each solution samples were placed into the wells. The plates were incubated for bacterial growth and examined for the presence of clear zones of inhibition around the wells

Antibiotics sensitivity: For the observation of antibiotics sensitivity test Disk diffusion method was performed [16]. Different nine antibiotics were tested over the isolates. The appropriate antimicrobial-impregnated disks were placed on the surface of the MH agar plate inoculated with each isolate. The zones of inhibition around the disks were observed and the diameters were measured. 
The bacteria were isolated from different five samples of yoghurt and were identified as Lactobacillus spp. by observing their colony morphology, physiological as well as some biochemical characteristic. Microscopic examination showed the isolates were Gram-positive rod shaped (Figure. 1), non-motile, catalase nega-

Table1. Morphological, physiological and biochemical characteristics of isolated Lactobacillus

\begin{tabular}{|c|c|c|c|c|c|}
\hline $\begin{array}{l}\text { Biochemical and physi- } \\
\text { ological characteristic }\end{array}$ & Sample-1 & Sample-2 & Sample-3 & Sample-4 & Sample-5 \\
\hline Colonies morphology & $\begin{array}{l}0.5 \mathrm{~mm} \text {, white, } \\
\text { rough, irregular, } \\
\text { and round, flat }\end{array}$ & $\begin{array}{c}0.6 \mathrm{~mm}, \text { brownish } \\
\text { rough, circular, raised }\end{array}$ & $\begin{array}{l}0.5 \mathrm{~mm} \text {, creamy white, } \\
\text { smooth, round, raised }\end{array}$ & $\begin{array}{l}0.4 \mathrm{~mm} \text {, white, circu- } \\
\text { lar, dull, flat }\end{array}$ & $\begin{array}{l}0.4 \mathrm{~mm} \text {, creamy white, } \\
\text { smooth, irregular, flat }\end{array}$ \\
\hline Gram stain & + & + & + & + & + \\
\hline Motility test & Non motile & Non motile & Non motile & Non motile & Non motile \\
\hline Catalase test & - & - & - & - & - \\
\hline Endospore test & - & - & - & - & - \\
\hline $0.4 \%$ phenol tolerance & + & + & + & + & + \\
\hline Milk coagulation activity & + & + & + & + & + \\
\hline $\mathrm{NaCl}$ tolerance & + & + & + & + & + \\
\hline
\end{tabular}

\section{Optimal PH and growth}

Maximum growth of isolated Lactobacillus of different sample was observed at different PH Maximum growth of isolated Lactobacillus from sample 1(ND's) yoghurt was observed at $\mathrm{pH} 5.5$ $(\mathrm{OD}=1.067)$ similarly, maximum growth of sample 2(KDC) was also observed at PH $5.5(\mathrm{OD}=1.042)$, sample 3(DDC plain) at $\mathrm{PH}$ $6.5(\mathrm{OD}=1.039)$, sample 4 (DDC probiotic) at PH4.5 (OD=1.025) and sample 5(ju -ju dhau ) was observed at PH 6.5 (OD=1.048), after $24 \mathrm{~h}$ of incubation in an anaerobic condition. The results are shown in Table 2.

Table 2. Optimal PH and growth.

\begin{tabular}{|c|c|c|c|c|c|}
\hline PH value & \multicolumn{5}{|c|}{ Growth rate at OD $_{560}$} \\
\hline & Sample 1 & Sample 2 & Sample 3 & Sample 4 & Sample 5 \\
\hline 2.5 & 0.214 & 0.408 & 0.211 & 0.276 & 0.662 \\
\hline 3.5 & 0.282 & 0.948 & 0.978 & 0.496 & 0.985 \\
\hline 4.5 & 0.648 & 1.032 & 1.003 & 0.823 & 1.025 \\
\hline 5.5 & 1.067 & 1.042 & 1.039 & 1.002 & 0.991 \\
\hline 6.5 & 1.016 & 1.012 & 1.035 & 1.03 & 0.899 \\
\hline 7.5 & 1.012 & 1.022 & 1.004 & 0.956 & 0.834 \\
\hline 8.5 & 0.264 & 0.715 & 0.944 & 0.881 & 0.586 \\
\hline
\end{tabular}

\section{Tolerance to $\mathrm{NaCl}$}

Table 3. Growth rate on Various $\mathrm{NaCl}$ concentration of isolated Lactobacillus spp

\begin{tabular}{|c|c|c|c|c|c|}
\hline \multirow[t]{2}{*}{$\mathrm{NaCl}$ conce $^{\mathrm{n}}$} & \multicolumn{5}{|c|}{ Growth rate at $\mathrm{OD}_{560}$} \\
\hline & Sample 1 & Sample 2 & Sample 3 & Sample 4 & Sample 5 \\
\hline $1 \%$ & 1.267 & 1.258 & 1.108 & 1.325 & 1.329 \\
\hline $2 \%$ & 1.168 & 1.22 & 1.105 & 1.312 & $1-112$ \\
\hline $3 \%$ & 1.096 & 1.102 & 1.098 & 1.168 & 1.095 \\
\hline $4 \%$ & 1.064 & 0.973 & 1.094 & 1.299 & 0.857 \\
\hline $5 \%$ & 0.958 & 0.762 & 0.836 & 1.045 & 0.537 \\
\hline $6 \%$ & 0.916 & 0.711 & 0.354 & 0.618 & 0.227 \\
\hline 8.5 & 0.264 & 0.715 & 0.944 & 0.881 & 0.586 \\
\hline
\end{tabular}

tive and absence of Endospore. The isolates were able to coagulate milk and have the abilities to tolerate inhibitory substances such as $0.4 \%$ bacteriostatic phenol and showed growth in MRS broth containing 1-9\% $\mathrm{NaCl}$. The results are shown in (Table 1).
The isolates from sample were able tolerate 1-9\% $\mathrm{NaCl}$. But these organisms grow best at the broth containing $1 \% \mathrm{NaCl}$. The growth rate decreases with increase in $\mathrm{NaCl}$ concentration. The result are shown in Table 3.

\section{Bile salt tolerance}

Table 4. Growth rate at $\mathrm{OD}_{620}$ of isolated Lactobacillus from different sample at various 326 concentrations under different incubation time.

\begin{tabular}{|c|c|c|c|c|c|}
\hline Time in hour & control & $\mathbf{0 . 1 0 \%}$ & $\mathbf{0 . 3 0} \%$ & $\mathbf{0 . 5 0} \%$ & $\mathbf{1 \%}$ \\
\hline 0 & 0.218 & 0.213 & 0.211 & 0.217 & 0.201 \\
\hline 3 & 0.306 & 0.259 & 0.236 & 0.203 & 0.128 \\
\hline 5 & 0.578 & 0.368 & 0.321 & 0.16 & 0.062 \\
\hline 24 & 1.532 & 0.918 & 0.504 & 0.092 & 0.011 \\
\hline
\end{tabular}

Isolated Lactobacillus spp. were able to survive and multiply in $0.1,0.3,0.5$ and $1 \%$ bile acid. In Table 4 the optical density values against incubation time are given. The growth of Lactobacillus in MRS broth without bile was used as control. All the isolates showed different growth rate. With increase in the concentration of bile salt there the growth is decreased. The growth rate is also highly affected the increased in incubation period.

\section{Antibiotics activities}

Figure 2: Antibiotics Activity on isolated Lactobacillus spp by disk diffusion method. 
The isolates showed susceptibility and resistance pattern to all the nine antibiotics tested. The results are shown in Table 5. The isolates were more commonly sensitive to ampicillin, penicillin, erythromycin, nalidicxic acid, chloramphenicol, tetracycline, gentamycin and amoxicillin which presented diameter of inhibition zones between 10 and $35 \mathrm{~mm}$. The diameter of inhibition zones varied for different samples (Figure 2). The Antibiotics ciprofloxacin only showed resistance to all the five isolates.

Table 5. Zone of inhibition of selected antibiotics on isolated Lactobacillus spp from different 336 yoghurt sample using the disc diffusion method.

\begin{tabular}{|c|c|c|c|c|c|c|c|c|c|}
\hline \multicolumn{6}{|c|}{ Sample 1} & & & & \\
\hline Time in hour & control & $0.10 \%$ & $0.30 \%$ & $0.50 \%$ & $1 \%$ & & & & \\
\hline 0 & 0.215 & 0.252 & 0.172 & 0.207 & 0.234 & & & & \\
\hline 3 & 0.426 & 0.312 & 0.207 & 0.21 & 0.132 & & & & \\
\hline 5 & 0.868 & 0.437 & 0.302 & 0.152 & 0.038 & & & & \\
\hline 24 & 1.429 & 0.759 & 0.141 & 0.016 & 0.019 & & & & \\
\hline \multicolumn{6}{|c|}{ Sample 2} & & & & \\
\hline Time in hour & Control & $0.10 \%$ & $0.30 \%$ & $0.50 \%$ & $1 \%$ & & & & \\
\hline 0 & 0.144 & 0.103 & 0.113 & 0.11 & 0.138 & & & & \\
\hline 3 & 0.283 & 0.142 & 0.122 & 0.158 & 0.082 & & & & \\
\hline 5 & 0.538 & 0.462 & 0.19 & 0.035 & 0.036 & & & & \\
\hline 24 & 1.579 & 1.133 & 0.756 & 0.015 & 0.03 & & & & \\
\hline \multicolumn{6}{|c|}{ Sample 3} & & & & \\
\hline Time in hour & control & $0.10 \%$ & $0.30 \%$ & $0.50 \%$ & $1 \%$ & & & & \\
\hline 0 & 0.133 & 0.108 & 0.132 & 0.102 & 0.092 & & & & \\
\hline 3 & 0.342 & 0.149 & 0.142 & 0.122 & 0.072 & & & & \\
\hline 5 & 0.771 & 0.203 & 0.18 & 0.058 & 0.046 & & & & \\
\hline 24 & 1.817 & 0.628 & 0.486 & 0.031 & 0.027 & & & & \\
\hline \multicolumn{6}{|c|}{ Sample 4} & & & & \\
\hline Time in hour & Control & $0.10 \%$ & $0.30 \%$ & $0.50 \%$ & $1 \%$ & & & & \\
\hline 0 & 0.21 & 0.231 & 0.212 & 0.225 & 0.192 & & & & \\
\hline 3 & 0.256 & 0.233 & 0.251 & 0.21 & 0.126 & & & & \\
\hline 5 & 0.782 & 0.322 & 0.432 & 0.068 & 0.082 & & & & \\
\hline 24 & 1.442 & 1.202 & 0.746 & 0.034 & 0.021 & & & & \\
\hline \multicolumn{10}{|c|}{ Sample 5} \\
\hline \multirow[t]{2}{*}{ Isolates from } & \multicolumn{9}{|c|}{ Diameter of inhibition zone in $\mathrm{mm}$} \\
\hline & AP10 & P10 & T30 & CHL30 & AM10 & CIP5 & E15 & NA10 & G10 \\
\hline Sample 1 & $26 s$ & $17 \mathrm{~S}$ & $28 \mathrm{~s}$ & $26 s$ & $21 \mathrm{~s}$ & $\mathrm{R}$ & $29 \mathrm{~s}$ & $22 \mathrm{~s}$ & $24 \mathrm{~s}$ \\
\hline Sample 2 & $30 \mathrm{~s}$ & $20 \mathrm{~s}$ & $31 \mathrm{~s}$ & $28 \mathrm{~s}$ & $22 \mathrm{~s}$ & $\mathrm{R}$ & $31 \mathrm{~s}$ & $27 \mathrm{~s}$ & $25 \mathrm{~s}$ \\
\hline Sample 3 & $25 s$ & $10 \mathrm{~s}$ & $35 s$ & $31 \mathrm{~s}$ & $18 \mathrm{~s}$ & $\mathrm{R}$ & $30 \mathrm{~s}$ & $24 \mathrm{~s}$ & $28 \mathrm{~s}$ \\
\hline Sample 4 & $28 \mathrm{~s}$ & $15 \mathrm{~s}$ & $31 \mathrm{~s}$ & $29 \mathrm{~s}$ & $25 \mathrm{~s}$ & $\mathrm{R}$ & $28 \mathrm{~s}$ & $30 \mathrm{~S}$ & $18 \mathrm{~s}$ \\
\hline Sample 5 & $27 \mathrm{~s}$ & $18 \mathrm{~s}$ & $32 \mathrm{~s}$ & $26 \mathrm{~s}$ & $29 \mathrm{~s}$ & $\mathrm{R}$ & $25 \mathrm{~s}$ & $17 \mathrm{~S}$ & $21 \mathrm{~s}$ \\
\hline
\end{tabular}

sample using the disc diffusion method.

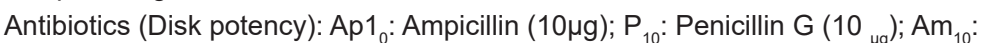

Amoxicilline $(10 \mu \mathrm{g}) ; \mathrm{T}_{30}$ : Tetracycline $(30 \mu \mathrm{g}) ; \mathrm{CHL}_{30}$ : Chloramphenicol $(30 \mu \mathrm{g}) ; \mathrm{E}_{15}$ :

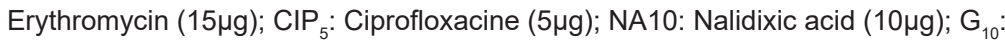

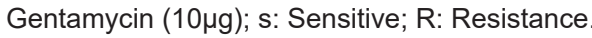

\section{Antimicrobial activity}

The isolated spp. was examined to their antimicrobial activity. For this, spp. was detected against the indicator microorganisms Salmonella thyphi, Escherichia coli, Bacillus subtillis and staphylococcus aureus. These organisms are occasionally found as food borne microorganisms that might cause gastroenteritis. The re- sults revealed that the antibacterial activity of the five isolated Lactobacilli could inhibit the pathogenic bacteria tested, however at different inhibition levels as shown in Table 6 (Figure 3). Of the five isolates tested, only isolates from sample 2 can inhibited the growth of all the pathogens used as indicators. But other samples 1, 3 4, and 5 only inhibit the indicator organism Bacillus and Escherichia coli. 
Table 6. Antimicrobial activities of isolated lactobacillus on indicator microorganism.

\begin{tabular}{|c|c|c|c|c|}
\hline \multirow{2}{*}{ Isolates from } & \multicolumn{3}{|c|}{ Indicator microorganism } \\
\cline { 2 - 5 } & \multicolumn{3}{|c|}{ Diameter of inhibition zone in mm } \\
\hline No & Escherichia coli & Bacillus subtilis & Salmonella typhi & Staphylococcus aureus \\
\hline 1. sample 1 & $16 \mathrm{~mm}$ & $11 \mathrm{~mm}$ & 0 & $14 \mathrm{~mm}$ \\
\hline 2. sample 2 & $20 \mathrm{~mm}$ & $14 \mathrm{~mm}$ & 0 \\
\hline 3. sample 3 & $18 \mathrm{~mm}$ & $14 \mathrm{~mm}$ & 0 \\
\hline
\end{tabular}

Figure 3: Inhibition of different indicator organism by isolated Lactobacillus spp.

\section{Discussion}

The isolated rod shaped, gram positive, catalase negative, non -motile with other mention biochemical properties in Table 1, bacteria were isolated from different yoghurt sample from Kathman$\mathrm{du}$ valley. These isolates were assigned as Lactobacillus [17]. The $\mathrm{pH}$ factor directly affects the bacterial growth. Probiotic bacteria are mostly delivered in a food system so these must have to tolerate acid in order to survive in the human gastrointestinal tract.

In this study we observed the growth of the isolated Lactobacillus spp. in various $\mathrm{pH}$ value ranges from 2.5 to 8.5 to determine whether the isolated spp. can grow in acidic and alkaline conditions and also to detect the optimal $\mathrm{pH}$ value for good growth. It was found that the bacteria were able to survive from extreme acidic (2.5) to basic pH (8.5) and for optimal growth the variation with the sample is viewed. Probiotic organism have to stand in a high salt concentration in a human gut [18]. In our study the lactobacillus isolated from all sample were able to survive in1-9\% of $\mathrm{NaCl}$ and the good growth is seen at $1 \% \mathrm{NaCl}$.

This study also indicate that the growth rate decreases with the increase in $\mathrm{NaCl}$ concentration. The probiotic bacteria must able to resist the bile salt in order to survive in the human intestine and $0.3 \%$ bile is the maximum concentration present in the healthy men [19]. So, for the human consumption the probiotics should be bearable to $0.3 \%$ bile concentration [20]. Here, $0.1-1 \%$ of bile salt concentration was used and our isolated Lactobacillus spp. from all five yoghurts are able to tolerate up to $0.3 \%$ of bile concentration.

In control conditions there were rapid increase in growth of all three cultures with an increase in incubation period up to $24 \mathrm{~h}$ and there was rapid decrease observed in all cultures with increase concentration especially above $0.3 \%(0.5 \%$ and $1 \%)$ of bile salt.

Antibiotic resistance of microorganisms used as probiotic is of growing concern. Bacteria used as probiotics may serve as host of antibiotic resistance genes, which can be transferred to pathogenic bacteria [21]. The antibiotic resistance of pathogenic bacteria is an increasing medical problem. Therefore, the antibiotic susceptibility test should be integrated for the safety assessment of the desired property of the probiotic Lactobacilli.

Our isolates were all sensitive to penicillin, ampicillin, amoxicillin, tetracycline, erythromycin nalidixic acid and chloramphenicol, but only resistance to ciprofloxacin. Resistance to ampicillin ciprofloxacin and vancomycin are commonly found in the genus Lactobacillus [22]. Since the isolates tested in this work were not resistant to any of antibiotics, except ciprofloxacin they could be safe for use by animals and eventually by humans, and their lack of resistance also indicates that they may not contribute to the transfer of resistance to other microorganisms.

Resistance of all Lactobacillus spp to ciprofloxacine could be due to their natural and intrinsic resistance, probably due to the cell wall structure and membrane impermeability, complemented in some cases by potential efflux mechanisms [23]. Regarding antibacterial activities the good probiotics should present their antimicrobial actions particularly to the pathogens in the gastrointestinal tract. The inhibitory activity of Lactobacillus spp. varies within the strains [24]. Lactobacilli are highly competitive due to their production of several antimicrobial compounds such as organic acids, hydrogen peroxide, reuterin and bacteriocins [25].

In this study, Staphylococcus aureus, Salmonella typhi, Bacillus subtilis and Escherichia coli were used as the test bacteria because they are occasionally found as food borne microorganisms that might cause gastroenteritis. The results revealed that the 
antibacterial activity of the five isolated Lactobacilli could inhibit all test pathogenic bacteria however at different inhibition levels as shown in (Table 5). The isolated sample 1, 3, 4 and 5 showed the most antibacterial potency to E. coli and Bacillus whereas the isolated sample 2 demonstrated the highest potency to the entire organism used as indicator.

\section{Conclusion}

Those food having the health benefit beyond the basic nutrient are captivating the consumers. Extensive research is currently directed toward increasing our understanding of such functional foods and the food industry is trying to fulfill these demands by developing products with measurable health benefits. Food with the probiotics is gaining consumer interest.

The isolated Lactobacillus spp. from different yogurt samples which most of the people of Kathmandu use to consume fulfills the required criteria of a probiotics. These isolated strains were able to survive in a favourable environment of human gastrointestinal tract such as high salt, low $\mathrm{pH}$ and high bile concentration. Therefore, these Lactobacillus isolates show their potential to be used as probiotic. This spp. is hence a good candidate for further investigation under in vitro as well as in vivo conditions to elucidate their potential beneficial health effects and their possible application as novel probiotic species in the food industry.

\section{Acknowledgement}

We would like to thank Professor Dr. Rameshwar Adhikari, Research Center for Applied Science and Technology, Tribhuvan University, Nepal for his continuous support, guidelines and encouragement towards this research.

\section{References}

1. Morrow LE, Gogineni V, Malesker MA (2012) Probiotics in the intensive care unit. Nutrition in Clinical Practice 27 (2): 235-241.

2. Ambadoyiannis G, Hatzikamari M, Litopoulou-Tzanetaki ET, Zanetakis N (2005) Probiotic and technological properties of enterococci isolates from infants and cheese. Food Biotech 18(3): 307-325.

3. Catanzaro J, Green L (1997) Microbial ecology and probiotics in human medicine (Part II). Alternative Medicine Review 2(4): 296-305.

4. Ohashi Y, Ushida K (2009) Health-beneficial effects of probiotics: its mode of action. Animal Science Journal 80(4): 361-371.

5. Parvez S, Malik KA, Ah Kang S, Kim HY (2006) Probiotics and their fermented food products are beneficial for health. Journal of Applied Microbiology 100(6): 1171-1185

6. Hayes SR, Vargas AJ (2016) Probiotics for the prevention of pediatric antibiotic associated diarrhea. Explore (New York, N.Y.) 12(6): 463466.

7. Tulumoglu S, Yuksekdag ZN, Beyatli Y, Simsek O, Cinar B, Yaşar E (2013) Probiotic properties of Lactobacilli species isolated from children's feces. Anaerobe 24: 36-42.

8. De Simone C, Ciardi A, Grassi S, Lambert Gardini S, Tzantzoglou V, Trinchieri S, Jirillo E (1992) Effect of Bifidobacterium bifidum and Lactobacillus acidophilus on gut mucosa and peripheral blood B lymphocytes, Immunopharmacology and Immunotoxicology 14(1-2): 331-340.
9. Keer C, Melkebeke L, Vertriest W, Hoozee G, Schoonenberghe E (1983) Growth of Lactobacillus species on different media. Journal of the Institute of Brewing 89: 361-363.

10. De Man JC, Rogosa M, Sharpe ME (1960) A medium for the cultivation of lactobacilli. Journal of Applied Bacteriology 23: 130-135

11. Hartemink R, Domenech V R, Rombouts FM (1997) LAMVAB - A new selective medium for the isolation of lactobacilli from faeces, J Microbiol Meth 29(2): 77-84.

12. Sneath N S, Mair M E, Sharpe, Holt JC (2009) Berger's manual of systematic bacteriology. Baltimore, Williams and Wikins 3: 1209-1234.

13. Hoque F, Akter KM, Hossain MSM, Rahman MM, Billah, et al. (2010) Isolation, Identification and Analysis of Probiotic Properties of Lactobacillus Spp. From Selective Regional Yoghurts. World Journal of Dairy \& Food Sciences 5(1): 39-46.

14. Graciela FVD, Maria PT (2001) Food Microbiology Protocols. Probiotic 269 Properties of Lactobacilli, Spencer. Humana Press Inc, Totowa.

15. Vinderola G, Capellini B, Villarreal F, Suarez V, Quiberoni A, et al. (2008) Usefulness of a simple set of in-vitro tests for the screening and identification of probiotic candidate strains for dairy use. LWT-Food Science and Technology 41(9): 1678-1688.

16. De S, Sena S, Bhowmik I, Maity S, Bhowmik S (2016) Isolation, Characterization and Identification of Lactobacilli spp. And Study of Its Pharmacological Activity In Vitro. International Journal of Recent Scientific Research 7(11): 14296-14298.

17. Hammes WP, Weiss N, Holzapfel WH (1991) The genera Lactobacillus and Carnobacterium in the prokaryotes. Handbook on the Biology of Bacteria: Ecophysiology, Isolation, Identification, Applications.

18. Gilliland SE, Staey TE, Bush LJ (1984) Importance of bile tolerance of Lactobacillus acidophilus used as a dietary adjunct. Journal of Dairy Science 67(12): 3045-3051.

19. Graciela FV D, Maria PT (2001) Food Microbiology Protocols. Probiotic Properties of Lactobacilli, Spencer. Humana Press Inc, Totowa.

20. Quwehand AC, Vesterlund S (2004) Antimicrobial components from lactic acid bacteria. Lactic Acid Bacteria Microbiological and Functional Aspects. New York.

21. Temmerman R, Pot B, Huys G, Swings J (2003) Identification and antibiotic susceptibility of bacterial isolates from probiotic products. International Journal of Food 288 Microbiology 81(1): 1-10.

22. Klein G, Pack A, Bonaparte C, Reuter G (1998) Taxonomy and physiology of probiotic lactic acid bacteria. International Journal of Food Microbiology 41(2): 103-125.

23. Ammor MS, Flórez AB, Mayo B (2007) Antibiotic resistance in non-enterococcal lactic acid bacteria and bifidobacteria. Food Microbiology 24(6): 559-570.

24. Maragkoudakis,PG, Zoumpopoulou GH, Miaris G, Kalantzopoulos, B Pot, Tsakalidou E (2006) Probiotic potential of Lactobacillus strains isolated from dairy products International Dairy Journal 16(3): 189199.

25. Marie Kaktcham, Francois, Zambou, Florence, Fonteh, Victor, Sieladie, Mbiapo Félicité, Tchouanguep (2011) Characterization of bacteriocin produced by Lactobacillus rhamnosus $1 \mathrm{~K}$ isolated from traditionally fermented milk in the western highlands region of Cameroon. New York Science Journal 4: 121-128.

26. Walker DK, Gilliland SE (1983) Relationship among bile tolerance, bile salt deconjugation and assimilation of cholesterol by Lactobacillus acidophilus. J Dairy Sci 76(4): 956-961.

27. Saarela M (2002) Gut bacteria and health foods-the European perspective. I J Food Microbiol 78(1-2): 99-117. 


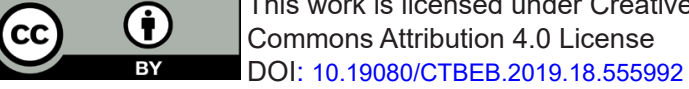

\section{Your next submission with Juniper Publishers}

will reach you the below assets

- Quality Editorial service

- Swift Peer Review

- Reprints availability

- E-prints Service

- Manuscript Podcast for convenient understanding

- Global attainment for your research

- Manuscript accessibility in different formats

( Pdf, E-pub, Full Text, Audio)

- Unceasing customer service

Track the below URL for one-step submission

https://juniperpublishers.com/online-submission.php 